\title{
EFFECTS OF ORGANIC MANURES AND GREEN MANURING ON GROWTH, YIELD, ECONOMICS AND QUALITY OF LEMONGRASS (CYMBOPOGON FLEXUOSUS L.) IN CUSTARD APPLE (ANNONA SQUAMOSA L.) BASED AGRI-HORTI SYSTEM
}

\author{
Anjali Massey, RN Meena ${ }^{1}$ and Ashvin Kumar Meena* \\ Department of Agroforestry, Institute of Agricultural Sciences, Banaras Hindu University, \\ Varanasi (Uttar Pradesh) India-221005
}

Keyword: Cymbopogon flexuosus, Organic manures, Green manuring, Growth, Yield, Quality, Economics

\begin{abstract}
A field experiment was conducted to explore the effects of organic manures and green manuring practices on growth, yield attributes, quality and economics of lemongrass (Cymbopogon flexuosus L.) under custard apple (Annona squamosa L.) based agri-horti system. The findings indicated that growth, yield attributes and yield as well as oil composition, soil nutrient status, microbial populations were significantly increased due to the use of both organic manures and green manuring. The significantly higher results were obtained with vermicompost $(2.5 \mathrm{t} / \mathrm{ha})+$ Azotobacter, which was found superior over other practices in terms of growth, yield attributes, oil composition and its quality and soil nutrient status as well as economics of crop cultivation.
\end{abstract}

\section{Introduction}

Lemongrass (Cymbopogon flexuosus L.) is a perennial multi cut aromatic grass belonging to Poaceae and genus Cymbopogon which consist of 80 species. Lemongrass prefers tropical or subtropical climates with temperature range of 10 to $33^{\circ} \mathrm{C}$ and favorable rainfall range from 700 to $3000 \mathrm{~mm}$ uniformly distributed throughout the year. The plant possesses strong lemony odor due to high content of aldehyde citral which has two geometric isomers, geranial (Citral A) (Shahi et al. 2005). Lemongrass is well known for its essential oil which contains citral as the major constituent and its oil is extensively used for scenting, waxes, polishes, deodorants and also used in teas (Husain et al. 2004). Lemongrass responded very positively to the application of organic manure. Vermicompost, farm yard manure and green manuring were found to be effective to enhance the root formation, elongation of stem and production of biomass in lemongrass. Studies have also been reported that bio-fertilizer such as Azotobacter spp. offers an attractive way to replace chemical fertilizer, resulting a significant increase in plant height, root length, and dry matter production (Mirzaei et al. 2021). Biofertilizers help to improve the soil properties and maintain the soil fertility (Lopes et al. 2020). Sharma et al. (2005) reported that green manuring has also been found to have positive effects on some aromatic and medicinal plants. Hence, the present experiment was conducted to find out the effects of organic manures and green manuring on growth, yield attributes and quality of lemongrass.

\section{Materials and Methods}

A field experiment was carried out at Agricultural Research Farm (Rajiv Gandhi South Campus), Institute of Agricultural Sciences, Banaras Hindu University, Barkachha, Mirzapur,

*Author for correspondence: <ashvin.agro@gmail.com>. ${ }^{1}$ Department of Agronomy, Institute of Agricultural Sciences Banaras Hindu University, Varanasi (Uttar Pradesh) India-221005. 
Uttar Pradesh, during kharif 2018-19 in custard apple based agri-horti system. The laboratory work was carried out at the department of Agronomy, Banaras Hindu University, Varanasi, Uttar Pradesh. Soil of the experimental field was sandy clay loam in nature, low in organic carbon content $(0.32 \%)$ (Walkley and Black 1934). Chemical analysis of initial composite soil sample (0$20 \mathrm{~cm}$ layer) showed that it had $152.36 \mathrm{~kg} / \mathrm{ha}$ alkaline $\mathrm{KMnO}_{4}$ oxidizable nitrogen (Subbiah and Asija 1956), $17.0 \mathrm{~kg} / \mathrm{ha}$ available phosphorus (Olsen et al. 1954), $211.65 \mathrm{~kg} / \mathrm{ha} 1 \mathrm{~N}$ neutral ammonium acetate exchangeable potassium (Hanway and Heidel 1952), and $\mathrm{pH}$ of the soil was 6.45 (1:2.5 soil: water ratio) (Jackson 1973). Experiment laid out in a split plot design with four organic manures treatments were allotted to main plot i.e. $\mathrm{M}_{1}$-Vermicompost (2.5 t/ha), $\mathrm{M}_{2}-\mathrm{FYM}$ (5.0 t/ha), $\mathrm{M}_{3}$-Vermicompost $(2.5 \mathrm{t} / \mathrm{ha})+$ Azotobacter, and $\mathrm{M}_{4}$-FYM (5.0 t/ha) + Vermicompost (2.5 t/ha), four green manuring treatments viz. $\mathrm{G}_{1}$-clusterbean, $\mathrm{G}_{2}$-cowpea, $\mathrm{G}_{3}$ - Sunn hemp (Crotalaria juncea) and $\mathrm{G}_{4}$-dhaincha were allotted to sub plot. Slips of krishna variety were planted at specified distance $(40 \times 60 \mathrm{~cm})$. For observation, five plants from each net plot were randomly selected and used for growth parameters at 60 days after planting (DAP) and at harvest. The herb yield of lemongrass was recorded from net area of each plot and converted into quintal per ha. Aerial parts of five randomly selected plants in each treatment were collected, out of which a sample of $200 \mathrm{~g}$ was separated and subjected to hydro-distillation using a clevenger apparatus for estimation of oil content. The oil content was noted down and the essential oil was collected and dried it over anhydrous sodium sulphate and stored at $4^{\circ} \mathrm{C}$ until the $\mathrm{GC}$ analysis and then essential oil per cent was calculated by multiplying volume of oil with sp. gravity of oil i.e. $0.88 \mathrm{~g}$ $\mathrm{cm}^{-3}$. The fungal, bacterial and actinomycetes population in soil were estimated by standard plate count method using Martin's for fungi (Martin 1950), and nutrient agar medium for bacteria and actinomycetes (Allen 1959). Microbial population was calculated and expressed as number of cells $\times 10^{\mathrm{n}} / \mathrm{g}$ soil.

\section{Results and Discussion}

Results regarding growth parameters presented in Table 1 showed that application of vermicompost $(2.5 \mathrm{t} / \mathrm{ha})+$ Azotobacter $\left(\mathrm{M}_{3}\right)$ produced significantly higher plant height (135.21 $\mathrm{cm}$ ), number of leaves/plant (64.21), number of tillers/plants (21.82), number of leaves/tiller (58.53), leaf area index $\left(145.36 \mathrm{~cm}^{2}\right)$ and dry weight $(126.51 \mathrm{~g})$ at 60 days after planting (DAP) and at harvesting $148.68 \mathrm{~cm}, 72.14,25.02,67.01,162.44 \mathrm{~cm}^{2}$ and $176.74 \mathrm{~g}$, respectively. However, all the growth parameter was found lowest with sole application of FYM $\left(\mathrm{M}_{2}\right)$. Amongst the green manuring practices, manuring with dhaincha $\left(\mathrm{G}_{4}\right)$ resulted in significantly higher plant height $(123.33 \mathrm{~cm})$, number of leaves/plant (52.55), number of tillers/plants (17.06), number of leaves/tiller (48.98), leaf area index $\left(131.51 \mathrm{~cm}^{2}\right)$ and dry weight of lemongrass $(112.29 \mathrm{~g})$ at 60 DAP. The similar trend was also followed at harvesting stage (Table 1). Addition of organic manure and green manuring improve the soil organic matter, it provides essential nutrients to plants. Azotobacter fixes nitrogen in soil and provides it to plants for various growth activities which have positive effect on growth and development of lemongrass plant (Chen et al. 2006). Similar findings were also reported by Verma et al. (2014).

The data on yield attributes viz. herb yield, oil content (\%), vitamin C (mg/100 g), ascorbic acid (mg/100 g), essential oil (\%), ash (\%), and total chlorophyll $(\mathrm{mg} / 100 \mathrm{~g})$ of lemongrass as influenced by organic manures and green manuring are presented in Table 2. Application of vermicompost $(2.5 \mathrm{t} / \mathrm{ha})+$ Azotobacter $\left(\mathrm{M}_{3}\right)$ produced significantly highest herb yield, oil content, vitamin $\mathrm{C}$, ascorbic acid, essential oil, ash per cent, and total chlorophyll at harvest. The lowest herbage yield and yield attributes were observed in sole application of FYM $\left(\mathrm{M}_{2}\right)$. In case of green manuring, significantly higher herb yield, oil content, vitamin $\mathrm{C}$, ascorbic acid, essential oil, ash per cent and total chlorophyll were recorded in manuring with dhaincha $\left(\mathrm{G}_{4}\right)$. However, the lowest 


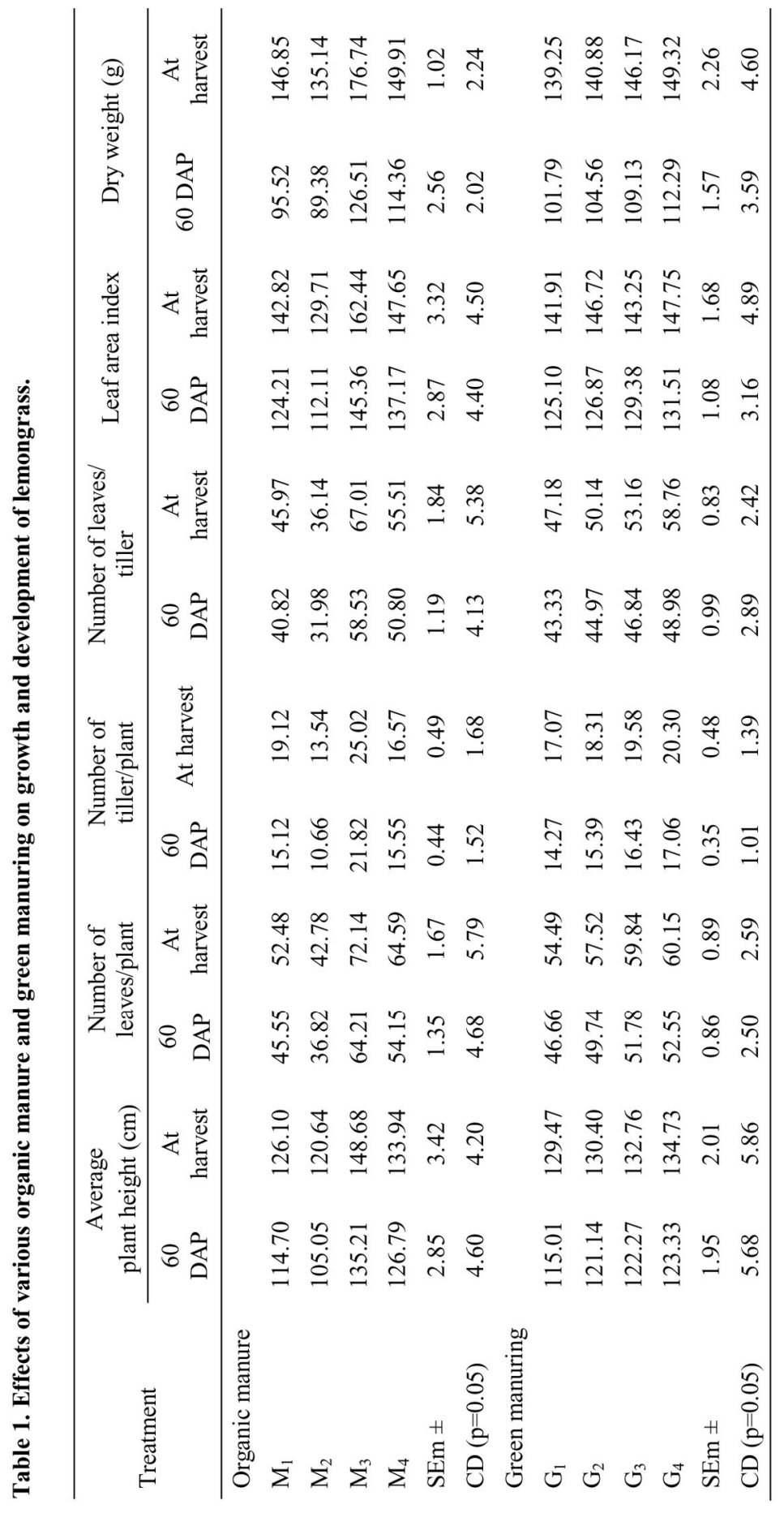




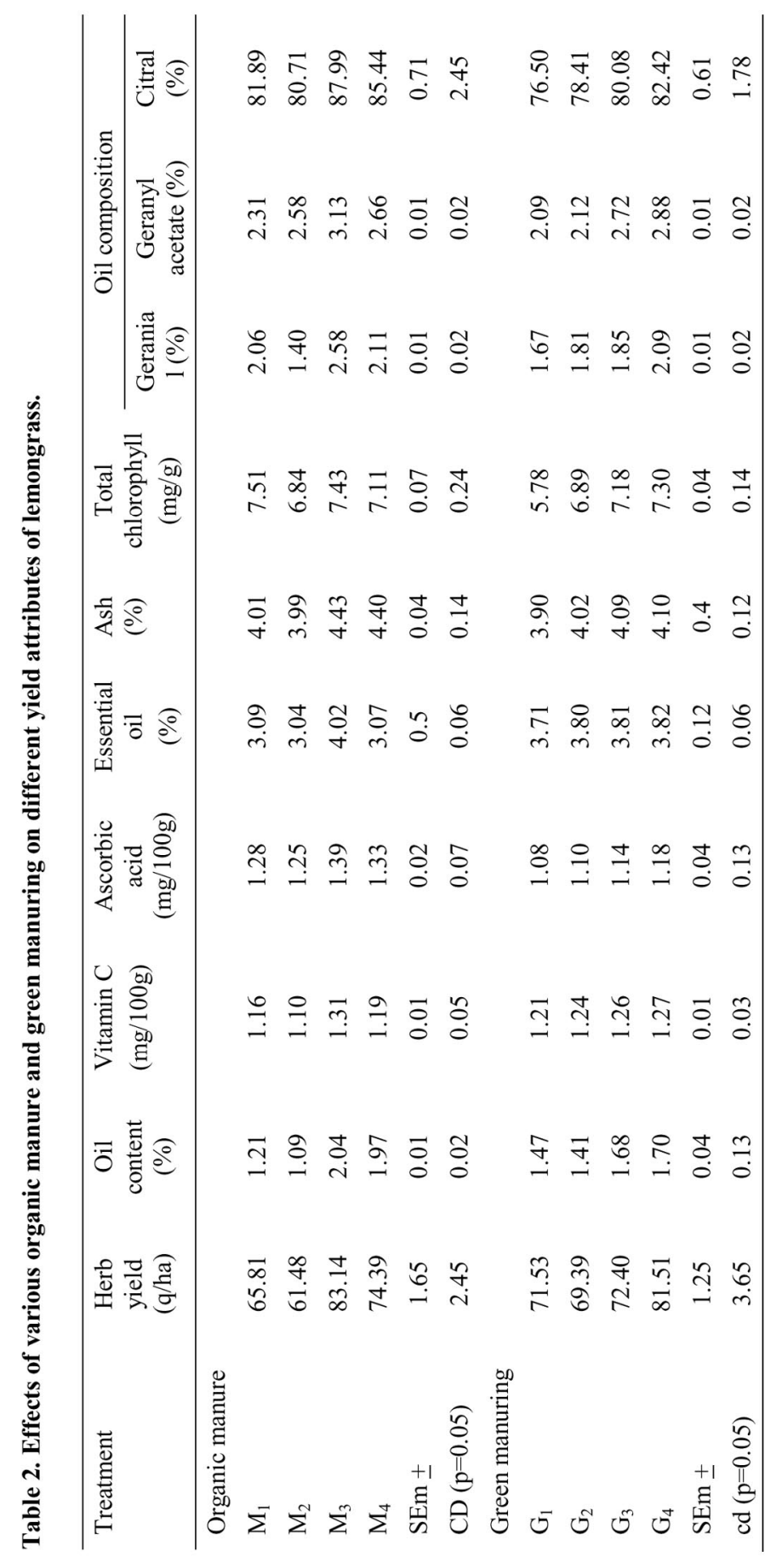


herbage yield and other yield attributes were found in treatment $\mathrm{G}_{1}$. Sastry et al. (2014) reported that herb and oil yield of citronella plants increased significantly with the application of organic manures. Azotobacter have ability to fix atmospheric nitrogen into the soil and also converts non available form of phosphorus and nitrogen into available one hence provide better nutrition to lemongrass, ultimately resulted in increasing yield and yield attributes which is in agreement with the findings of Kulmi and Tiwari (2006).

Results regarding quality parameters presented in Table 2 indicated that application of vermicompost $(2.5 \mathrm{t} / \mathrm{ha})+$ Azatobacter $\left(\mathrm{M}_{3}\right)$ produced significantly the highest geranial per cent (2.58), geranyl acetate per cent (3.13) and citral per cent (87.99). However, the lowest geranial per cent (1.40) and citral per cent (80.71) were observed with sole application of FYM $\left(\mathrm{M}_{2}\right)$, while the lowest geranyl acetate per cent (2.31) was found in $\mathbf{M}_{1}$. Among the green manuring practices, manuring with dhaincha $\left(\mathrm{G}_{4}\right)$ resulted in significantly higher geranial per cent (2.09), geranyl acetate per cent (2.88) and citral per cent (82.42), it remains statistically at par with sunn hemp $\left(\mathrm{G}_{3}\right)$. The lowest geranial per cent (1.67), geranyl acetate per cent (2.09) and citral per cent (76.50) were observed in manuring with clusterbean $\left(\mathrm{G}_{1}\right)$. The results are in conformity with findings of Ayyobi et al. (2013).

The microbial population were affected significantly with the application of different organic manures and green manuring practices (Table 3$)$. The application of vermicompost $(2.5 \mathrm{t} / \mathrm{ha})+$ Azotobacter $\left(\mathrm{M}_{3}\right)$ resulted in maximum population of bacteria $\left(19.06 \times 10^{6}\right)$, fungi $(23.79 \mathrm{mg} / 100$ $\mathrm{g}$ soil) and actinomycetes $(31.51 \mathrm{mg} / 100 \mathrm{~g}$ soil). However, the minimum bacteria, fungi, actinomycetes population were found in sole application of FYM $\left(\mathrm{M}_{2}\right)$. Among green manuring practices, manuring with dhaincha $\left(\mathrm{G}_{4}\right)$ showed significantly higher bacterial population $(15.72 \times$ $\left.10^{6}\right)$, fungi $(19.07 \mathrm{mg} / 100 \mathrm{~g})$ and actinomycetes $(24.85 \mathrm{mg} / 100 \mathrm{~g})$, respectively. This remains statistically at par with green manuring with sunn hemp $\left(\mathrm{G}_{3}\right)$. Addition of organic inputs enhanced the microbial counts in soil, which probably due to the bio-availability of growth-promoting substances. Similar findings were also reported by Masto et al. (2006).

Application of vermicompost $(2.5 \mathrm{t} / \mathrm{ha})+$ Azatobacter $\left(\mathrm{M}_{3}\right)$ resulted in significantly higher available nitrogen $(196.34 \mathrm{~kg} / \mathrm{ha})$, phosphorus $(32.38 \mathrm{~kg} / \mathrm{ha})$, potassium $(186.91 \mathrm{~kg} / \mathrm{ha})$ and maximum reduction in bulk density (1.19) in the soil after crop harvest (Table 3). In case of green manuring, significantly higher availability of soil nutrients and maximum reduction in bulk density of soil were recorded with manuring with dhaincha $\left(\mathrm{G}_{4}\right)$. Organic manures and green manuring enhance the organic matter status of soil which further improves soil physical as well as microbiological activities and increases the availability of plant nutrients (Kumar and Dhar 2010). Decomposition of organic manures releases various phenolic and aliphatic acids which solubilize phosphates and other phosphate bearing minerals and thereby lowers the phosphate fixation and increases its availability (Dotaniya et al. 2013). Bulk density were also significantly affected due to higher organic carbon content in treatments which had better soil aggregate and larger macro pore space (Das et al. 2002).

Economic parameters of lemongrass + custard based agri-horti system were significantly affected due to different organic manures and green manuring practices (Table 4). Application of vermicompost (2.5 tonnes/ha) + Azatobacter $\left(\mathrm{M}_{3}\right)$ recorded significantly highest gross return (Rs 7,01,059), net return (Rs 5,56,356) and B: C ratio (4.68). Among green manuring practices manuring with dhaincha recorded significantly highest gross return (Rs 5,51,498), net return (Rs 3, 93,730) and B: C ratio (3.52) whereas the lowest in FYM $\left(\mathrm{M}_{2}\right)$ and dhaincha $\left(\mathrm{G}_{4}\right)$.

As the organic farming gaining momentum for growing crops this study will be helpful to grow lemongrass by using the combination of organic manures and green manuring practices in an efficient way. Application of organic manures and green manuring practices were found to be 
Table 3. Effects of various organic manure and green manuring on available soil nutrients, bulk density and microbial population.

\begin{tabular}{|c|c|c|c|c|c|c|c|c|}
\hline \multirow[t]{2}{*}{ Treatment } & \multicolumn{3}{|c|}{$\begin{array}{l}\text { Available nutrients } \\
\qquad(\mathrm{kg} / \mathrm{ha})\end{array}$} & \multicolumn{2}{|c|}{$\begin{array}{l}\text { Bulk density } \\
\left(\mathrm{mg} / \mathrm{m}^{3}\right)\end{array}$} & \multicolumn{3}{|c|}{$\begin{array}{l}\text { Microbial } \\
\text { population }\end{array}$} \\
\hline & $\mathrm{N}$ & $\mathrm{P}$ & $\mathrm{K}$ & Initial & $\begin{array}{c}\text { After } \\
\text { harvest }\end{array}$ & $\begin{array}{c}\text { Bacteria } \\
\left(10^{6}\right)\end{array}$ & $\begin{array}{c}\text { Fungi } \\
(\mathrm{mg} / 100 \mathrm{~g})\end{array}$ & $\begin{array}{c}\text { Actinomyctes } \\
(\mathrm{mg} / 100 \mathrm{~g})\end{array}$ \\
\hline \multicolumn{9}{|c|}{ Organic manuring } \\
\hline $\mathrm{M}_{1}$ & 187.69 & 26.40 & 174.98 & 1.35 & 1.22 & 12.47 & 15.81 & 18.92 \\
\hline $\mathrm{M}_{2}$ & 185.68 & 25.37 & 170.94 & 1.37 & 1.26 & 7.46 & 11.76 & 14.19 \\
\hline $\mathrm{M}_{3}$ & 196.34 & 32.38 & 186.91 & 1.30 & 1.19 & 19.06 & 23.79 & 31.51 \\
\hline $\mathrm{M}_{4}$ & 188.22 & 28.94 & 180.75 & 1.32 & 1.20 & 16.15 & 21.23 & 23.25 \\
\hline $\mathrm{SEm} \pm$ & 1.90 & 0.61 & 1.74 & 0.04 & 0.03 & 0.30 & 0.39 & 0.04 \\
\hline $\mathrm{CD}(\mathrm{p}=0.05)$ & 4.51 & 2.11 & 3.56 & NS & NS & 1.03 & 1.35 & 1.38 \\
\hline \multicolumn{9}{|c|}{ Green manuring } \\
\hline $\mathrm{G}_{1}$ & 180.68 & 22.76 & 176.63 & 1.31 & 1.28 & 12.03 & 16.23 & 20.96 \\
\hline $\mathrm{G}_{2}$ & 182.63 & 27.51 & 178.46 & 1.33 & 1.25 & 13.47 & 17.83 & 21.46 \\
\hline $\mathrm{G}_{3}$ & 187.79 & 28.60 & 181.76 & 1.30 & 1.21 & 14.23 & 18.46 & 22.59 \\
\hline $\mathrm{G}_{4}$ & 189.83 & 30.22 & 183.74 & 1.35 & 1.20 & 15.72 & 19.07 & 24.85 \\
\hline $\mathrm{SEm} \pm$ & 1.69 & 0.32 & 1.55 & 0.03 & 0.02 & 0.12 & 0.17 & 0.23 \\
\hline $\mathrm{CD}(\mathrm{p}=0.05)$ & 3.95 & 0.95 & 4.53 & NS & NS & 0.34 & 0.50 & 0.58 \\
\hline
\end{tabular}

Table 4. Effects of various organic manure and green manuring on economics of lemongrass under custard apple based agri-horti system.

\begin{tabular}{lcccc}
\hline Treatment & $\begin{array}{c}\text { Cost of cultivation } \\
(\mathrm{Rs} / \mathrm{ha})\end{array}$ & $\begin{array}{c}\text { Gross return } \\
(\mathrm{Rs} / \mathrm{ha})\end{array}$ & $\begin{array}{c}\text { Net return } \\
\text { (Rs/ha) }\end{array}$ & $\begin{array}{c}\text { Benefit: } \\
\text { cost ratio }\end{array}$ \\
\hline Organic manure & & & & \\
$\mathrm{M}_{1}$ & 143889 & 472832 & 328943 & 3.29 \\
$\mathrm{M}_{2}$ & 170639 & 419354 & 248714 & 2.46 \\
$\mathrm{M}_{3}$ & 144703 & 701059 & 556356 & 4.68 \\
$\mathrm{M}_{4}$ & 171453 & 584803 & 413350 & 3.46 \\
$\mathrm{SEm} \pm$ & & 12530 & 12530 & 0.08 \\
$\mathrm{CD}(\mathrm{p}=0.05)$ & & 43362 & 43362 & 0.29 \\
$\mathrm{Green}_{\text {manuring }}$ & & & & \\
$\mathrm{G}_{1}$ & 157254 & 548218 & 390964 & 3.43 \\
$\mathrm{G}_{2}$ & 157725 & 528161 & 370437 & 3.47 \\
$\mathrm{G}_{3}$ & 157767 & 550171 & 392232 & 3.49 \\
$\mathrm{G}_{4}$ & 157939 & 551498 & 393730 & 3.52 \\
$\mathrm{SEm} \pm$ & 10990 & 10990 & 0.06 \\
$\mathrm{CD}(\mathrm{p}=0.05)$ & & 32080 & 32080 & 0.18 \\
\hline
\end{tabular}


the best for enhancing growth, yield, chemical composition of oil and enhancing soil physical properties as well as economics of lemongrass. Application of vermicompost $2.5 \mathrm{t} / \mathrm{ha}+$ Azatobacter and green manuring with dhaincha were recommended for better growth, yield, oil quality, relative economics and soil nutrient status.

\section{References}

Allen ON 1959. Experiments in soil bacteriology, 3rd educational Burgess publishing Cooperation. Minneapolis, USA.

Ayyobi H, Peyvast GA and Olfati JA 2013. Effect of vermicompost and vermicompost extract on oil yield and quality of peppermint (Mentha piperata L.). J. Agric. Sci. 58: 51-60.

Chen J 2006. The combined use of chemical and organic fertilizers and bio-fertilizer for crop growth and soil fertility. In: International Workshop on Sustained Management of the Soil Rhizosphere System for Efficient Crop Production and Fertilizer use. Thailand.

Das K, Medhi DN, Guha B and Baruah BK 2002. Direct and residual effects of recycling of crop residues along with chemical fertilizers in rice-wheat cropping systems. Ann. Agric. Res. 23: 415-418.

Dotaniya ML, Prasad D, Meena HM, Jajoria DK, Narolia, GP, Pingoliya KK, Meena OP, Kumar K, Meena BP, Ram A, Das H, Chari MS and Pal S 2013. Influence of phytosiderophore on iron and zinc uptake and rhizospheric microbial activity. African J. Microbiol. Res. 7(51): 5781-5788.

Hanway JJ and Heidal H 1952. Soil analysis method used in lowa state soil testing loboratory. Iowa Agric. 57: $1-31$

Husain A 2004. Essential oil plants and their cultivation CIMAP, Lucknow. J. Medicinal and Aromatics Plant Sci. 5: 24-28.

Jackson ML 1973. Soil chemical analysis. Prentice Hall of India Pvt. Ltd., New Delhi.

Kulmi GS and Tiwari PN 2006. Integrated nutrient management in Ashwagandha (Withenia somnifera). Res. Crops 7: 895-899.

Kumar A and Dhar S 2010. Evaluation of organic and inorganic sources of nutrients in maize (Zea mays L.) and their residual effect on wheat (Triticum aestivum L.) under different fertility levels. Indian J. Agric. Sci. 80: 364-371.

Lopes MJS, Dias-Filho MB and Gurgel ESC 2021. Successful Plant Growth-Promoting Microbes: Inoculation Methods and Abiotic Factors. Front. Sustain. Food Syst. 5: 606454.

Martin JP 1950. Use of acid rose bengal and streptomycin for estimating soil fungi by plate method. Soil Fungi and Soil Sci. 69: 215-232.

Masto RE, Chhonkar PK, Singh D and Patra AK 2006. Changes in soil biological and biochemical characteristics in a long-term weld trial on a sub-tropical Inceptisol. Soil Bio. and Biochem. 38: 15771582.

Mirzaie M, Moghadam AL, Hakimi L and Danaee E 2020. The Plant growth promoting rhizobacteria (PGPR) improve plant growth, antioxidant capacity, and essential oil properties of lemongrass (Cymbopogon citratus) under water stress. Iranian J. Plant Physiol. 10 (2): 3155-3166.

Olsen SR, Cole CV, Watanabe FS and Dean LA 1954. Estimation of available phosphorus in soils by extraction with sodium bicarbonate. USDA Circ 939. Washington DC, USA.

Sastry K, Srinivas KV, Kumar NS, Kumar JK, Dharmendra AN and Sharma VU 2014. Variation in the essential oil content and composition of citronella (Cymbopogon winterianus) in relation to time of harvest and weather conditions. Ind. Crops and Products 61: 240-248.

Shahi A, Kaul M, Gupta R, Dutt P, Chandra S and Qazi G 2005. Determination of essential oil quality index by using energy summation indices in an elite strain of Cymbopogon citrates. J. Flavor Fragrance 20: $118-121$

Sharma SN, Prasad R and Singh S 2005. The role of mungbean residues and Sesbania aculeate green manure in the nitrogen economy of rice-wheat cropping system. Plant and Soil 172: 123-129. 
Subbiah BV and Asija GL 1956. A rapid procedure for assessment of available nitrogen in rice soils. Curr. Sci. 25: 259-260.

Verma SR, Shivran AC, Bhanwaria R and Singh M 2014. Effect of vermicompost and sulphur on growth, yield and nutrient uptake of fenugreek (Trigonella foenumgraecum L.). The Bioscan 9: 667-670.

Walkley A and Black IA 1934. An examination of Degtjareff method for determining soil organic matter, and proposed modification of the chromic acid tritation method. Soil Sci. 37: 29-38.

(Manuscript received on 5 October, 2019; revised on 11 September, 2020) 